Historia Slavorum Occidentis

2020, $\mathrm{nr} 4$ (27)

ISSN 2084-1213

DOI: $10.15804 /$ hso200404

\author{
RadosŁaW ŻuraWsKi vel Grajewski (ŁodŹ) \\ ORCID: 0000-0003-2176-140X
}

\title{
Polish-Czechoslovak relations in the assessments of British diplomacy in the initial stage of WWII
}

Słowa kluczowe: dyplomacja podczas drugiej wojny światowej, brytyjska dyplomacja wobec idei konfederacyjnej w czasie II wojny światowej, polski rząd na uchodźstwie w czasie II wojny światowej, władze czechosłowackie na uchodźstwie w czasie II wojny światowej, konfederacja polsko-czechosłowacka

Keywords: diplomacy of World War II, British diplomacy and the idea of confederations in Europe in WWII, Polish government in exile during WWII, Czechoslovak authorities in exile during WWII, Polish-Czechoslovak confederation

Abstract: The idea of a Polish-Czechoslovak confederation was strongly supported by London in the initial stages of World War II. The differences in the attitude towards the Soviet Union proved to have been the most important obstacle to close Polish-Czechoslovak collaboration.

Polish-Czechoslovak relations during the Second World War have a rich historiography ${ }^{1}$. It is difficult to examine the issue in a small work in a way that would

1 D. Brandes, Exil v Londýně 1939-1943, Velká Británie a její spojenci Československo, Polsko a Jugoslávie mezi Mnichovem a Teheránem, Praha 2003 (German edition: Großbritanien und seine osteuropäischen Alliierten 1939-1943, München 1988); T. Kisielewski, Federacja środkowo-europejska. Pertraktacje polsko-czechosłowackie 1939-1943, Warszawa 1991; P.S. Wandycz, Czechoslovak-Polish Confederation and the Great Powers 1940-1943, Indiana University Publications, Slavic and East European Series, Vol. 3, Bloomington 1956; R. Žáček, 
significantly extend the existing literature. Therefore, I shall limit myself to showing these relations in the context of contacts of Polish and Czechoslovak diplomats with their British counterparts and the reports and analyses of the Foreign Office (further referred to as the FO). So there is no need to undertake a detailed presentation of the direct relations developed between the parties involved. I shall focus on their image among British diplomacy.

The adopted time frame is between October 1939 and November 1940. The first date marks the moment of establishing political relations between the Edvard Beneš group, aspiring to represent the independent Czechoslovak movement in exile, and the government of the Republic of Poland (RP), created in France after the September defeat. The second is the date of the announcement of the Polish-Czechoslovak declaration on the intention to establish closer cooperation between the two countries. It was the first public announcement of intent to build some sort of a federative community. This paper presents an analysis of only the initial stage of the Polish-Czechoslovak negotiations, as seen from the perspective of the FO. Describing them in their entirety would require a far more comprehensive study.

The starting points for the Polish authorities in exile and the Czechoslovak independence milieu were significantly different. The former enjoyed full recognition as a legitimate body outside the territory of the occupied country, maintaining full legal continuity and representing an ally of the United Kingdom (UK), at war with Germany. The Czechoslovak independence representatives did not enjoy this status. They could not demonstrate any mandate to represent the Czechoslovak state whose very existence was questioned, or justify the thesis on its legal continuity within the First Czechoslovak Republic ${ }^{2}$. A fully recognized government of the RP in exile was in existence, acting pursuant to the 1935 Constitution, with PM Gen. Władysław Sikorski and President Władysław Raczkiewicz as head of state. The Czechoslovak National Committee (Československý národní výbor - ČSNV), recently recognized only by France (14 Nov. 1939) was still due to be recognised by the UK (20 Dec. 1939) not as a representative of a state but of the "Czechoslovak peoples", autho-

Projekt československo-polské konfederace v letech 1939-1943, Opava 2001. About general British-Czechoslovak relations during the Second World War see: M.D. Brown, Dealing with Democrats. The British Foreign Office and the Czechoslovak Émigrés in Great Britain, 1939 to 1945, Frankfurt am Main 2006.

2 R.P. Żurawski vel Grajewski, Kształtowanie się polskich i czechosłowackich władz na uchodźstwie w początkowym okresie II wojny światowej. Status prawny - podobieństwa i różnice, [in:] Dwa państwa trzy narody. Ustroje polityczne Polski i Czechosłowacji (1918-1939), ed. J. Adamczyk, Warszawa 2004, pp. 161-173. 
rized to conduct negotiations mostly in matters related to the Czechoslovak army formed in France ${ }^{3}$.

In spite of significant differences, both entities shared many similarities. Their home countries were occupied by Germany (notably, Poland's eastern territories were under Soviet occupation at that time), and their asylum and the basis of their independent actions were the Western powers at war with the Third Reich: first France and, after June 1940, only the UK. This common fate gave rise to reflection on the possibilities of promoting closer cooperation between Polish and Czechoslovak political structures in exile. The Polish side saw the possibility of building a political force in Central Europe, able to resist the pressure of both Berlin and Moscow, while the Czechoslovak side treated Poland's cooperation instrumentally as an ad hoc tool for strengthening its international position and equating its political status with that of the Polish authorities. At the same time, the conditions and prospects for the development of Polish-Czechoslovak relations attracted the interest of British diplomacy, seeking a new post-war order in Central and Eastern Europe, of which both countries had a chance to be an important element.

The initiative to establish relations came from Czechoslovak side. On 4 October, after Sikorski had formed the government, Beneš sent a congratulatory telegram on behalf of the "Czechoslovak nation" to him and received a courteous answer. The correspondence was carefully noted in the memoranda of Sir Eric Phips (UK Ambassador in France) to Lord Halifax ${ }^{5}$.

Since the autumn of 1939, the British inspired their two allies to expand their cooperation. During Sikorski's visit to London (14-20 November), Lord Halifax notified him that "in the future there must be very close military cooperation between Poland and Czechoslovakia" ${ }^{6}$ and based on it the security of both countries. This was in line with the concepts of regional federations that were to form the core of

3 Idem, Brytyjsko-czechostowackie stosunki dyplomatyczne (październik 1938-maj 1945), Warszawa 2008, pp. 82-124.

4 Text of both telegrams: docs. 5 and 6 in: Czechoslovak-Polish Negotiations of the Establishment of Confederation and Alliance 1939-1944, Prague 1995 (CzPNECA), p. 33.

5 The National Archives (TNA) FO 417/40, C 16519/72/12, E. Phipps' letter to Halifax of 13 Oct. 1939, at 112.

6 Quotations from: M.K. Kamiński, Edvard Beneš kontra gen. Wtadystaw Sikorski. Polityka władz czechosłowackich na emigracji wobec rządu polskiego na uchodźstwie 1939-1943, Warszawa 2005, p. 19; see: J Němeček, Československo-polské vztahy na počátku 2. světové války: složitá cesta k jednání o konfederaci, Český časopis historický 2 (2002), p. 348. 
post-war Europe, already presented in October by the British to August Zaleski, the Polish Minister of Foreign Affairs. According to that line of thinking, a federation of Poland, ČSR and Hungary would be established in Central and Eastern Europe, and the first step towards it would be fostering Polish-Czechoslovak cooperation ${ }^{7}$. Zaleski welcomed these ideas, and the British took care of the appropriate publicity of Sikorski's meetings with Beneš which took place on 18 and 19 November. "The Daily Telegraph" and "The Morning Post" published a report on the talks, declaring them being "with a view to closer collaboration between these two victim States in a future". Brief information about the Polish-Czech rapprochement with the prospect of closer cooperation between the two allies was also prepared for the House of Commons 9 This testified to the genuine British interest in the matter. However, restoration of the Czechoslovak statehood was still suspended, and the adjective "Czechoslovak" carefully avoided and replaced by the phrase "the Polish Government and the Czech representatives" to define the parties to the dialogue. The position of Slovakia in the planned construction, whether as an independent entity or together with the Czech Republic, was still an open question ${ }^{10}$. Neither the Poles nor the British realized that, two days after the meeting with Sikorski, Beneš had communicated to Ivan Maisky, the Soviet ambassador in London, the need of a close union between the ČSR and the USSR, even with a prospect of a federation. Earlier - in September he suggested the need of a common border at the expense of Poland ${ }^{11}$. This showed lack of honesty on his part in his relations with the northern neighbour.

Similar conclusions can be drawn from a conversation held on 22 November between Beneš and Reginald Leeper, head of the Political Intelligence Department (PID) of FO. According to Beneš, as long as Poles did not give up the idea of "great Poland" (i.e. within borders from 1939), detailed Polish-Czechoslovak talks about

7 M.K. Kamiński, Edvard Beneš kontra, p. 19.

8 TNA FO 371/22900, k. 145, Gen. Sikorski on London Talks, clipping from “The Daily Telegraph" and "The Morning Post" of 20 XI 1939.

9 TNA FO 371/22900, Draft Statement in the House of Commons, p. 144 - probably prepared by F.K. Roberts - an official of the Central Department of the FO.

10 However, in the House of Commons there were also voices of support for the reconstruction of the ČSR, see the statement by Labour MP Philip John Noel-Baker, of 14 XII 1939, [in:] Bitva o Československo $v$ britském veřejném minění. K třetímu výročí mnichovske dohody, sestavili B. Beneš a J. Šuhaj, London 1941, p. 57.

11 Ref. 625, entry from 22 IX 1939, [in:] Аокументы внешней политики 1939 год, т. 22, кн. 2, 1 сентлббя-31 декабря 1939 г. Москва 1992, pp. 121-122; M.K. Kamiński, Czy Edvard Beneš mógł być dla Polski wiarygodnym partnerem? Arcana 4 (1997) 16, pp. 128-129, 134-135. 
the future of mutual relations were pointless and the best solution would be a small Poland within its ethnographic boundaries. This would not raise the USSR's concerns and it would not oppose the federation between Poland and the ČSR. Thus, at the beginning of a discussion about the Polish-Czechoslovak federation, he made Moscow's support for this idea the prerequisite of its implementation ${ }^{12}$.

However, in the early days of the war, it was not only Beneš who aspired to take the leadership of the representatives of Czechoslovak independence. A competitive political centre was created by Milan Hodža, a Slovak and a former PM in the First Republic $^{13}$. On 22 November, he established the Slovak National Council (SRN) in Paris, seeking to achieve Slovakia's greater independence in a state shared with the Czech Republic, and not excluding more far-fetched combinations of federations in which Slovakia would be an equal player. Hodža presented his concept of a future security system in Central Europe to the British and Poles in a memorandum sent to the FO and the Polish Ministry of Foreign Affairs (MSZ) on 28 XI 1939. He emphasized the need for close trade and political cooperation between Poland, ČSR, Austria, Hungary, Yugoslavia, Romania and Bulgaria. In his opinion, these countries should strive to strengthen their relations so as to be able to resist foreign domination in the future. In this concept, Slovakia - a partner of the Czech Republic in a common state - would facilitate the agreement between Czechs and Poles ${ }^{14}$.

The negotiations regarding the recognition of ČSNV by the British and Polish governments were extended until December 1939. The British finally recognized it as the representation of "Czechoslovaks" abroad while the Poles were reluctant to make this decision. Jan Ciechanowski, the Secretary General of the MSZ, informed Frank Savery, the counsel of the British Embassy to the Polish government in Angers, that the decision would be untimely, especially in view of the political divisions within the Czechoslovak emigres, which was evidenced by the creation of Hodža's SRN ${ }^{15}$.

\footnotetext{
12 M.K. Kamiński, Edvard Beneš kontra, pp. 19-20. Beneš also told Ambassador Raczyński about the possible participation of Poland (but within strictly ethnographic borders) in the Danube federation. E. Raczyński, W sojuszniczym Londynie, Warszawa 1989, p. 59.

13 More about the rivalry between Beneš and Hodža in J. Kuklík, J. Němeček, Proti Benešovi! Česka a slovenská protibenešovská opozice v Londýně 1939-1945, Praha 2004; eidem, Hodža versus Beneš. Milan Hodža a slovenská otázka v zahraničním odboji za druhé světové války, Praha 1999.

14 Ref. 152, of 28 XI 1939, [in:] Dokumenty československé zahraniční politiky. Od rozpadu Česko-Slovenska do uznání československé prozatímní vlády 1939-1940. (16. březen 1939-15 červen 1940), Praha 2002, (DČZP), pp. 320-324.

15 M.K. Kamiński, Edvard Beneš kontra, p. 21.
} 
However, discussions on this matter continued between Juraj Slávik, the former envoy of the ČSR in Warsaw, and Edward Raczyński - the Polish ambassador in London, minister August Zaleski, deputy minister of the MSZ - Zygmunt Garliński, and Witold Adam Korsak - an official in charge of the Czechoslovak affairs in the MSZ. While conducting talks on the recognition of the ČSNV, Poland simultaneously sought to take up the issue of closer relations between the two countries in the future in the form of a federation. Having taking note of this, Beneš forbade Slávik to associate the matter of ČSNV's recognition by the Polish government with any political negotiations regarding the prospect relations and excluded the possibility of signing secret agreements with the Poles without authorisation from the UK and France. He permitted only general declarations in favour of the idea of a federation ${ }^{16}$. At the same time, he addressed the FO with question if England, by virtue of the alliance with Poland of 25 VIII 1939, also guaranteed Polish territorial integrity to the USSR, to which he received a categorical denial. For him, this information was of key importance if he was even to consider cooperation with Poland. In his opinion, a prospect of a conflict with the USSR was a factor undermining the project of strengthening bonds with the RP. Moreover, he immediately informed Maisky about this position of British authorities through Zdenek Fierlinger, a former representative of the ČSR in Moscow ${ }^{17}$.

The future of Central Europe, including Polish-Czechoslovak relations, was also the subject of deliberations of British experts whose opinions had some influence on the FO views. The interviews carried out by Raczyński on this issue in late 1939 and early 1940 revealed a number of diverse views on the possible evolution and desirable directions thereof. The British experts among Raczyński’s interlocutors were represented by: Sir Bernard Pares, founder of the School of Slavic and East European Studies and publisher of the "Slavonic Review", and, since 1939, a government adviser on Russia; Professor Robert William Seton-Watson, an associate of FO PID, who was in close contact with Beneš and was influenced by his views. Reluctantly, they accepted the ideas of a federation in Central Europe. They found the Danube Federation difficult to form and rejected the return of the Habsburgs. A significant shift of the USSR to the West was considered a positive factor in the European politics. In this change they saw, above all, a serious blow to Germany.

16 School of Slavonic and East European Studies (SSEES) L. 3/4/8, a copy of J. Slávik's letter to E. Beneš of 9 I 1940 and E. Beneš telegram to J. Slávik of 11 I 1940 (without pagination further referred to as w.p.).

17 Ref. 46, of 6 II 1940, [in:] Československo-sovètské vztahy v diplomatických jednáních 1939-1945. Dokumenty, díl 1 (březen 1939-červen 1943), Praha 1998 (hereinafter: ČSVDJ), p. 118. 
They claimed that the RP was losing its ethnically non-Polish territory, which would resolve the dispute with Russia (as the USSR was referred to). This would enable Russia to secure the existence of smaller Slavic states and positively influence the balance of power in Europe.

Sir Alfred Eckhart Zimmern, a professor of international relations at the University of Oxford, perfectly knowledgeable about the internal Czechoslovak relations, had other views on the role of the USSR in Central Europe. Raczyński presented him as an example of a line of reasoning among British experts according to which the relations with Moscow might hinder communication with some "Czech political directions" (i.e. with Benešs school of thought) and indicated that Poland would find more understanding and opportunities for cooperation in groups gathered around Štefan Osuský, the Czechoslovak envoy in Paris and Hodža, a former PM. Raczyński also informed the MSZ that, in mid-December 1939, in a London house a private meeting had been held for British journalists addressed by Beneš. He mentioned, among other issues, a new "'Russia' Soviet policy”. At the same time: "He clearly expressed the opinion that the Soviet occupation of the Baltic states, and the aggression on Finland were caused by the necessity for Russia to secure its European borders from the possibility of further German advances to the East”. These views were shared and made public by James Louis Garvin, a well-known British journalist, employed by "The Observer", a left-liberal weekly, and a friend of both Seton-Watson and Beneš. Raczyński also discussed the idea of a federation with Leeper, apparently not realizing that he was partly repeating the opinions he had heard from Beneš. The head of the PID believed that if, victorious over the Germans, the USSR abstained from the war, it would probably be possible to rebuild a "smaller Poland" bereft of its eastern territories. In this scenarion, Leeper saw the need to create a Polish-Czech-Slovak federation. If, however, the USSR decided to go to war and was defeated or considerably weakened, the idea of rebuilding a "bigger Poland", or even two federations (Danubian and North-Eastern) in Central and Eastern Europe could be considered. The latter would be created by Poland and Ukraine. The $\mathrm{RP}$ and the ČSR would be separate yet closely cooperating state entities. In a report for the MSZ, the Polish ambassador emphasized that his observations referred to the directions of intellectual thinking rather than the political circles of the British establishment ${ }^{18}$.

18 Quotations from Raczyński’s talks: The Polish Institute and Sikorski Museum in London, PRM-19-9-IV, E. Raczyński's report for the Foreign Minister in Angers on 30 I 1940 English views on the future of the Czech No. $49 / \mathrm{Cz} / \mathrm{tj} / 88$. 
Hubert Ripka, a former official of the Ministerstvo Zahraničních Věcí (MZV), and the then member of the ČSNV conducted a similar interview among British intellectual circles of academics on the prevailing views regarding the future of Czechoslovakia. While in his report he did not divulge any names, his observations and conclusions were similar to those of Raczyński. Ripka recognized that the UK ensured better reception for the Czechoslovak case than France but the British were the most willing to shirk the responsibility for the Danube region and did not engage either against the ČSR or against Hungary. He considered the Slovak issue the most important one in relation to the future of the Czechoslovak idea. As he wrote, "the three important Englishmen” warned him that Slovaks - like Hodža and Osuský - presented a possibility of Slovak autonomy, not within the ČSR but in Hungary. Other interlocutors spoke of a Polish-Czech-Slovak-Hungarian Federation, possibly including also Romania and even the Ukraine. Most of Ripka's interviewees in London and Oxford talked about the revival of the ČSR, but, as he emphasized, these opinions could not be treated as positions of the British government ${ }^{19}$.

At this stage of the war, apart from the general idea of a federation of Central and Eastern Europe, in the absence of reliable predictions of the developments, both the FO and the British experts were unable to formulate a relevant and more specific political programme. Nevertheless, suggestions regarding the need for Polish-Czechoslovak rapprochement were constantly reported to the Polish government. In early February 1940, Frank Savery discussed this issue again with Ciechanowski, under the impression that the French were responsible for the Polish reserve towards the ČSNV, warning the Poles against a hurried decision to cooperate because of suspicions of Beneš and uncertainty about the scale of support that he enjoyed among the Czechoslovak émigrés. Even Slávik unofficially advised the Poles to refrain from accepting any commitments on the part of the ČSNV until the disputes between the Czech and Slovak émigrés in France were resolved. In a conversation with Howard William Kennard, the British ambassador to the President of the RP, Minister Zaleski admitted openly that the internal disputes had been used to explain to Champetier de Ribes, the Undersecretary of State in the French Ministry of Foreign Affairs, the Polish government's failure to recognise the $\check{C} S N V^{20}$. Nevertheless, efforts were made to maintain the best possible contacts with Czechoslovak representatives and special consideration was

19 Archiv Ústavu Tomasza Garrigue Masaryka (hereinafter: AÚ TGM), fond 38, sign. 495/1, počet listu 188, Zpráva Dr. Huberta Ripky do Prahy z 1 května 1940, pp. 65-66.

20 M.K. Kamiński, Edvard Beneš kontra, pp. 34, 37. 
shown to Slávik who was included into a list of the diplomatic corps at the government of the RP, as Kennard informed the FO on 4 March.

On the other hand, Beneš launched a propaganda campaign in the UK about the recognition of the ČSNV as a provisional Czechoslovak government. On 8 March, at Chatham House (headquarters of the Oxford branch of the Royal Institute of International Affairs), with the consent of Halifax and awareness that an appropriate report would go to the FO, he gave a long speech. Realizing that the British looked favourably at the Polish-Czechoslovak negotiations regarding a federation, he publicly declared that the immediate goal of the Czechoslovak diplomacy was to establish a provisional government which would be a partner for talks with the Polish government. If succeed to achieve this, he promised to make efforts to conclude an alliance agreement with Poland, under the auspices of France and England, presenting this act as an introduction to the federation between the two countries. At that moment, the issue of borders was to be disregarded. Beneš stressed that the Polish-Czechoslovak relationship could positively affect Poland's relations with the USSR, even without ruling that the latter would share a border with the ČSR. Legal recognition by the Polish authorities in exile was what the Beneš group wanted to achieve. By showing the British the possibility of a federation of Poland and the ČSR, he also pointed to the formal inequality of both parties which was to be an obstacle to the progress of negotiations, and thus an argument in favour of changing the status of the $\check{C} S N^{21}$.

Meanwhile, the British started to perceive the intensifying dispute in the Czechoslovak circles of immigrants as a factor negatively affecting Polish-Czechoslovak relations. In April 1940, Hodža submitted a memorandum to the FO regarding changes in the composition of the ČSNV, a prerequisite for his agreement with Beneš ${ }^{22}$. At the same time, he told Robert Hamilton Bruce-Lockhart, a British government representative in the ČSNV, that if there was a final break between him and Beneš, he would go to Sikorski and resume talks about a Polish-Slovak federation (that was the British expert's guess ${ }^{23}$. This information had raised controversy among the

21 Ref. 61, of 9 III 1940, [in:] Dokumenty z historie československé politiky 1939-1943. Acta Occupationis Bohemiae \& Moraviae, díl 1, k vydání príipravila Libuše Otáhlová a Milada Cervinková, Praha 1966 (hereinafter: AOB ఓ M), p. 84.

22 Archiv Národního Muzea (hereinafter: ANM), fond E. Beneš, karton 48, nr 469/3, M Hodža memorandum on negotiations with E Beneš submitted to FO in IV 1940.

23 TNA 371/24288, C 6035/2/12, R.H. Bruce-Lockhart's memorandum of 22 IV 1940: Possibility of a Reconciliation between Dr. Beneš and M. Hodža, pp. 327-330. Hodža, from October 
officials of the Central Department of the FO. George Peregrine Young and Roger Mellor Makins clearly opposed to the possibility of resuming Hodža and Sikorski's talks, and hinted to Ciechanowski that the UK disapproved of similar steps. Frank Kenyon Roberts, on the other hand, reiterated that London did not undertake in any way to restore the former ČSR, and that Poles could not be blamed for their contacts with various Czech and Slovak political groupings, especially in the light of the events of September 1939, which confirmed the importance of Slovakia for the security of Poland. He warned that any British criticism of the Polish talks with Hodža would be negatively received by the Polish government. He merely suggested that the issue should be brought to the attention of the French and that they should be kept in constant contact, which was approved by William Strang, the then assistant under-secretary of state at the $\mathrm{FO}^{24}$. Ultimately, Savery was instructed to gather discreet information about the Poles' contacts with Hodža, without making any comments on the matter ${ }^{25}$.

At the same time, Beneš continued his diplomatic offensive in the FO. For sir Alexander Cadogan, the permanent under-secretary of state in FO, he prepared the "Memorandum o dnešním stavu akce pro osvobozeni Československa"26 sent after the politicians' talks on 26 April. Military issues were the pretext for this meeting, but the main purpose of Benešs visit to the $\mathrm{FO}$ was the recognition of the provisional Czechoslovak government. He indicated, among others, the international reasons in favour of the proposal. He argued that without the restoration of the ČSR, the existence of independent Poland would be impossible. He referred to the plans for cooperation with Poland, stressing that as long as the Czechoslovak side would not have the legal

1939, enjoyed more or less public support from the Polish authorities and had the opportunity to talk personally with Sikorski - J. Němeček, Od spojenectví k roztržce. Vztahy československé a polské exilové reprezentace 1939-1945, Prague 2003, pp. 45-46.

24 TNA FO 371/24288, C 6035/2/12, minutes by G.P. Young of 25 IV, F.K. Roberts along with the footnotes by W. Strang of 24 IV 1940, R.M. Makins of 25 IV 1940, pp. 322-323.

25 TNA FO 371/24288, C 6035/2/12, R.M. Makins letter to F. Savery of 30 V 1940, p. 331. About the attitude of the Polish Government towards Slovakia in D. Segeš, Partnerzy czy petenci? Stowacy i Stowacja w polityce rzadu RP na obczyźnie podczas II wojny światowej, thum. G. Gąsior, Gdańsk 2012 (Slovak edition: Dvojkríž siločiarach bieleho orla. Slovenská otázka $v$ politike pol'skej exilovej vlády za 2. Svetovej vojny, Bratislava 2009.

26 Archiv Ministerstva Zahranièních Věcí (AMZV), LA-D, oddíl 4, regál 70, č. 129, Politické věcí; lub 160; or 162, Record of the Points Raised by dr Beneš in his Conversation with Sir Alexander Cadogan on April 26 $6^{\text {th }}$ 1940; or AÚ TGM, fond 40/XVIII/13/7; or fond 37, sbírka Smutného, inscription $32 / 2$. 
status of the authorities equal to Poles, no negotiations would be possible, and the longer this state of affairs lasted, the more the parties would distance themselves from each other. He stated that the Czechs regarded this an act of injustice and humiliation, especially in the light of Poland's former conduct that "helped to murder" their country. It was blackmail calculated on the British fondness of the concept of a federation of Central and Eastern Europe. Cadogan was to draw conclusions from what Beneš said and wrote that if the British wanted to bring about a Czechoslovak-Polish agreement, they should provide both sides with an equal legal status.

However, the British-Czechoslovak negotiations regarding the recognition of the ČSNV as a provisional government were prolonged until the defeat of France in the summer of 1940. Until then, the Polish government did not recognize Czechoslovak political representation, even in the ČSNV formula, although talks on mutual cooperation were continued. At the crucial moment of this phase of the war, when the UK became the sole power left fighting and the last respite for political refugees from Europe conquered by Germany, Ciechanowski presented the state of Polish-Czechoslovak relations to Leeper and Bruce-Lockhart during a meeting on 15 June, informing them that the talks so far had resulted in a number of arrangements of cooperation in the future. At a peace conference ending the war, Poland was to strive to obtain the shortest possible border with Germany and the longest possible with the ČSR. The general staffs of both sides should coordinate common defence. Mention was also made of a possible Polish-Czechoslovakian federation, but only conditionally: if it was considered desirable as part of a general European order. Ciechanowski remarked that the Poles did not insist on this solution and did not try to impose it as a condition of mutual cooperation. They also did not demand from the Czechoslovak side guarantees of the eastern borders of the RP, realizing that they would not have obtained them under any circumstances. On the basis of his earlier conversations with Beneš, Bruce-Lockhart assessed that the principles of the Polish government corresponded with the views of the ČSNV leader on Polish-Czechoslovak cooperation. Ciechanowski admitted that the Polish government was willing to recognize the ČSNV in October 1939 but was stopped by the French. What is more, when he returned to the issue several months later, Paris warned him not to do it. The Polish diplomat also informed his interlocutors about conversations with Hodža, stating that this was his initiative, that he was not encouraged and offered no further meetings, and even referred to him as "a muddle-headed old gentleman"27. 
In late June and early July, the issue of rivalry between Beneš and Hodža for leadership of the Czechoslovak independence movement had already been resolved. Hodža's political position had been weakening for some time, and the defeat of France - a power that supported the anti-Beneš opposition - undermined the political and material basis of its functioning. Hodža deposited FRF 770,000 at the Bank of England in early June 1940 but when he tried to make use of the funds at the end of the month, it proved impossible. He was told that they were the property of the ČSNV and payment was denied. He then asked General Sikorski for intervention, who commissioned this task to Józef Ruciński, counsellor of the Polish embassy in London. Following suit without conviction, the counsellor did not find a good answer to the question asked by the FO as to why Hodža did not report this issue through the Czechoslovak deputation, only through the Poles ${ }^{28}$. On 1 July, intervention in the FO was repeated by Antoni Baliński, secretary of the Polish embassy in London - in an interview with Roberts. He explained the manner in which the Poles had dealt with this issue by referring to their traditional, close ties with the Slovaks and - as he supposed - Roberts knew of the "personal considerations" that had prevented Hodža from taking it through the Czechoslovak legation. In the FO, it was very well understood how these "personal considerations" prevented the Slovak politician from using the mediation of his own legation. After all, the history of the rivalry between him and Beneš was well known in the FO. Baliński was not encouraged to raise this topic again, considering that the initiative, in this respect, should belong to Hodža, which was not intended to be supported. Therefore, the Polish intervention did not bring about any results, apart from the dissatisfaction of the British side, that it took place at all. It was finally decided not to pay Hodža the contested money. The FO officials were just considering the recognition of the ČSNV as a provisional government. Under these circumstances, as Roberts stated, "we want to bring Dr. Hodža to heel", by suggesting that he made efforts to access money through Beneš. Finally, at the end of June, the Treasury refused to transfer the funds demanded by Hodža, explaining that the collapse of France had destroyed the value of its currency, and therefore it could not be exchanged for pounds. In fact, however, the decisions about Beneš's political support were made, and the activities of the opposition against him were ceased ${ }^{29}$.

M. Ciechanowski Secretary General of the Polish Foreign Office on Polish-Czechoslovak Relations, p. 155.

28 TNA, FO 371/24288 C 6035/2/12, J. Cook letter to F.K. Roberts of 24 VI 1940, p. 58.

29 TNA FO 371/24288, C 6035/2/12, minutes by F.K. Roberts of 25 VI and 2 VII 1940, R.M. Makins of 1 VII 1940, pp. 56-57. 
During the discussion preceding the recognition of the transformed ČSNV as a provisional government, the $\mathrm{FO}$ analysts also considered the decision in the context of its effects on Polish-Czechoslovak relations. In the Lord Halifax's communication with the War Cabinet, he stressed that an analysis of the likely negative effects of this step revealed that "further recognition would have antagonised Hungary and possibly offended the Polish Government". Meanwhile, as the Lord stated, the situation changed, because: "Common adversity has brought the Poles and Czechs closer together and no opposition is likely from the Polish Government to a Czecho-Slovak Provisional Government" 30 .

The Foreign Secretary's predictions about the position of the Polish authorities on the issue under discussion had turned out to be too optimistic. During the Polish Council of Ministers' meeting on 11 July, a number of objections were raised regarding the recognition of the ČSNV as the government. Stanisław Stroński, a minister without portfolio, pointed out that any establisment of a government-in-exile in England, which did not have the legitimacy of the Polish, Norwegian or Dutch governments, would not only weaken their position, but also give the Germans a pretext to create puppet governments in the occupied territories. Reservations were also made by Stanisław Kot and Generals Kazimierz Sosnkowski and Józef Haller. Only Henryk Strasburger, the Minister of the Treasury, Industry and Trade, was in favour of the Czechoslovak government, pointing to the danger of accusations by the British that the Polish side had resumed Czech-Polish disputes ${ }^{31}$. Ciechanowski raised the issue in a conversation with Strang on 12 July, stating that:

In the opinion of Polish Government it would be inequitable to give to $\mathrm{M}$. Beneš and his associates the same kind of recognition as had been given to the Polish Government. The latter were a legal Government with a President and all the apparatus of administration. They were the only Polish Government, since there was no Polish administration in occupied Poland. The position of M. Beneš was quite different, since there was a President, a Parliament and a Government in Bohemia, and his associates could not claim to be the only or the legal Czech Government ${ }^{32}$.

30 TNA FO 371/24289 C 7646/2/12, War Cabinet. Recognition of a Czecho-Slovak Provisional Government. Memorandum by the Secretary of State for Foreign Affairs (roughly) of July 1 1940, p. 27.

31 M.K. Kamiński, Edvard Beneš kontra, p. 50.

32 TNA FO $371 / 24289$ C 7646/2/12, note by W. Strang from a conversation with J. Ciechanowski of 12 VII 1940, p. 97. 
Ciechanowski warned the FO that the considered recognition of the Czechoslovak Provisional Government (CzPG) by London would be a breeding ground for German propaganda, increase German pressure on the Protectorate authorities, resulting even in German-inspired Czech protests. At the same time, he emphasized that the Polish government did not submit these comments in a spirit of hostility to the Czechs, with whom it maintained the best possible relations. He reminded them that the Poles provided significant help in creating the Czechoslovak army in France. However, in their opinion, there were "certain pitfalls" which were to be avoided. Strang assured Ciechanowski that the FO was aware of the difficulties he identified and noticed differences in the status between the Polish government and Beneš and his supporters. He warned, however, that although no final decisions had been made, it was almost certain that some sort of recognition would soon be offered to Beneš. "The most we should do, however, would be to recognise Dr. Beneš and his associates functioning as a provisional Government", he said. Ciechanowski proposed a slightly different formula of recognition of the "Czechoslovak National Committee as functioning as an interim Government”, which Strang promised to consider. Polish diplomacy, therefore, evidently sought to lower the rank of recognition for the Czechoslovak authorities in exile ${ }^{33}$.

At the same time, the Polish side intervened in the FO to free certain Czech and Slovak politicians remaining in opposition to Beneš, advertised as pro-Polish advocates of the Polish-Czechoslovak Federation, and interned by the British at Alexandra Palace (František Schwarz, Peter Prídavok, Vladimír Borin-Ležák, Karl Locher, Josef Waldmüller-Lesnievski). Tytus Filipowicz talked to Savery twice on this matter. The second time, he heard advice that the Poles should "in all that concerned their Czech policy consider Beneš as far more important than any other personality and so far as was in any way possible keep in close touch with him"34. Filipowicz was disappointed with the result of his intervention but stated that he had taken it to the knowledge and consent of General Sikorski and minister Kot. Savery considered Filipowicz an honest man but he remembered his former admiration for Piłsudski and suspected that he shared the Marshal's coldness towards the Czechs. Roberts was even more determined after the repeated Polish interventions on behalf of Hodža and his supporters. He informed Savery:

\footnotetext{
33 See also: J. Němeček, Od spojenectví k roztržce, pp. 68-69.

34 TNA FO $371 / 24289$ C 7815/2/12, F. Savery letter to F.K. Roberts of 16 VII and 11 VII 1940 with the minutes, pp. 93-96.
} 
That we had had to tell the Poles quite firmly that we did not regard them as qualified to speak for Dr. Hodža and his friends, and that in view of our own information we would advise them not to spend too much time and trouble on such matters. [...] I am afraid that in spite of all the outward signs of closer Polish-Czechs collaboration there are many Poles who are foolish enough to play with the idea of using the Slovaks against Czechs ${ }^{35}$.

Roberts admitted, however, that, besides Borin-Ležák, the British had no incriminating evidence against others and should not prolong their internment just because they did not sympathize with Beneš. He suggested that, regardless of the discouragement of the answer given to the Poles, the possibility of releasing four of the five mentioned persons should be sought and the Czechoslovak or Polish émigré authorities' intent on "hunting" political opponents should not be encouraged.

Meanwhile, after the recognition of the CzPG (21 July) by London, the Polish government did likewise by issuing, on 5 August, a note to the MZV Secretary of State, Hubert Ripka. As the newly formed government also included Juraj Slávik, the former Czechoslovak deputy to the Polish government, there was a need to appoint a new representative in his place, and Jan Skalický, the former Czechoslovak deputy in Lithuania was to be appointed. The Polish authorities accepted this candidacy, though with some resistance. During his time in Kaunas, Skalický was considered a supporter not only of anti-Polish but also pro-German politics, and Ciechanowski informed Savery about it. The British diplomat sent a relevant note about it to the FO. This was much to the surprise of Roberts who saw Skalický as a close associate of Beneš and his long-time former private secretary. The pro-German sympathies of Skalický were also strongly denied by Bruce-Lockhart. Similarly, the FO had the correspondence of Thomas Hildebrand Preston, the British consul in Lithuania, who, in 1938, described him as a wholehearted Frenchman and definitely anti-German. Of course, he declared that he was not "very pro-Polish" but, in his opinion, it was hardly surprising, given the "Polish flirtations with Germany". Roberts, however, was convinced that Skalický would implement this policy, which Beneš would choose, and he believed that it was aimed at close cooperation with the Poles. He felt that advising to appoint a representative of the Polish government to a "well known pro-Pole" such as Slávik would be unacceptable, because he would be declared a fascist in the Czech community, for the very reason that he was an envoy in Poland "under the Beck regime" during the 1938 Cieszyn incident. Finally, Roberts left 
Savery with a decision as to whether to try to influence the opinion of the Polish side about Skalický in any way. A representative of the UK to the Polish government told Ciechanowski, that there was nothing in the FO documents that could justify accusations of being pro-German and asked the Polish side to grant him trust "until he does something wrong" ${ }^{36}$. Interestingly, the Poles apparently remained silent in their talks with the British about the accusations of pro-Comintern activities that Skalický faced in his own group ${ }^{37}$. To Minister Zaleski this fact rather than love of everything German, was behind the efforts to change this candidacy.

Meanwhile, the FO had decided to improve the atmosphere in Polish-Czechoslovak relations, seeking a way to manifest their revival. In mid-August, Bruce-Lockhart suggested to Beneš that "the Czechs should do their bit to oil the wheels" in the process of rapprochement with the Poles and offered him an exchange of commanderin-chief visits to the Polish and Czechoslovak armies in the military camps of their partners in the UK. The Polish military would be visited by General Sergěj Ingr, the Czechoslovak MoD, and the Czechoslovak army by General Sikorski. In the FO, the initiative was enthusiastically assessed as having a very good impact on the British public opinion and extremely useful for propaganda in the other parts of the world. Recognizing the Poles as "the senior party" having a larger army, it was suggested that they would take the first step and send an invitation to the Czechoslovak side. Roberts sent the instructions in this spirit to Savery on 14 August $^{38}$. In turn, he addressed Brigadier Charles Bridge ${ }^{39}$ head of the newly created branch Number 4 Military Mission, with whom the Poles were cooperating in organizing underground operations in the occupied country ${ }^{40}$. During a meeting held on 20 August, Sikorski was perceived by Bridge as a person in favour of Czechs. He stated that he would welcome the invitation from General Ingr to visit the Czechoslovak army camp and return the favour. However, he declared to the brigadier that the Czechs "had often

36 TNA FO 371/24292 C 8548/8531/12, F. Savery letter to F.K. Roberts of 15 VIII 1940, p. 119; F.K. Roberts letter to F. Savery of 16 VIII 1940, pp. 120; letter by F. Savery to F.K. Roberts of 17 VIII 1940, p. 121.

37 M.K. Kamiński, Edvard Beneš kontra, p. 56.

38 TNA FO 371/24292 C 8531/8531/12, F.K. Roberts letter to F. Savery of 14 VIII 1940, p. 117.

39 TNA FO 688/29/2, letter of unknown author (probably F. Savery) to Ch. Bridge of 15 VIII 1940 w.p.

40 J. Bines, The Polish Country Section of the Special Operations Executive 1940-1946: A British Perspective, the doctoral dissertation submitted at the University of Stirling 2008, pp. 16-17, https://dspace.stir.ac.uk/bitstream/1893/929/1/z\%20Thesis.pdf. 
misunderstood the Polish point of view". He also assessed that Beneš had made a mistake by excluding Hodža from the composition of the CzPG and "expressed an opinion that if the Czechs remained strictly outside the Russian orbit, they and the Poles could work harmoniously together for the reconstruction of Europe". Moreover, Bridge was convinced that Sikorski did not have a good opinion on the fighting value of the Czechoslovak army. "He said that they had never really fought in France and had complained that the Poles were over-anxious to fight!!” he reported to Sav$\mathrm{ery}^{41}$. The conversation was very short, since Sikorski was "in a great hurry and also rather fussed", because he was about to leave for the Polish pilots' camp, where he was expecting a visit by King George VI. Under these circumstances, Bridge did not want to worry him any more about Ingr's visit and decided to settle for the generally favourable response of the Polish PM to the idea he had submitted ${ }^{42}$. At the same time, Savery initially recognized that he could not compel the Poles and the information for the FO was limited to expressing the hope that General Sikorski, as a "big brother", would be the first to introduce the initiative of inviting General Ingr to visit the Polish army ${ }^{43}$. However, after a conversation with Bruce-Lockhart on 25 August, he had a broader consultation among several FO officials, as a result of which Ambassador Kennard was instructed to re-intervene with the Poles, in order to get them to be the first to send an invitation to General Ingr. "It is only right that the initiative should come from the Poles since the Czechs have only a provisional government and they are both a smaller power and have a smaller army here", he stated ${ }^{44}$.

On 28 August, Kennard met with Minister Zaleski whom he warned about the intended discussion with Sikorski on the visit of the Czechoslovak minister of national defence, and he received information about the Polish government's consent to appointing Skalický representative of the CzPG to the Polish authorities. Then, on the

41 TNA FO 371/24292 C 8531/8531/12, letter by Ch. Bridge to F. Savery of 20 VIII 1940, p. 124. About the visit of King George VI to the Polish pilots' camp see: E. Raczyński, $W$ sojuszniczym Londynie, p. 89.

42 TNA FO 688/29/2 minutes with an illegible signature, probably by F. Savery, of 26 VIII 1940 w.p.

43 TNA FO 371/24292 C 8531/8531/12, F. Savery letter to F.K. Roberts of 22 VIII 1940, p. 123.

44 TNA FO 371/24292 C 8531/8531/12, minutes by F.K. Roberts of 27 VIII 1940, p. 122. $\mathrm{J}$. Friedl also writes about this incident (J. Friedl, Na jednym froncie. Czechosłowacko-polskie stosunki wojskowe 1939-1945, Warszawa 2011, p. 195), still there is no confirmation of the information that Sikorski "made it obvious that it is General Ingr who should take the initiative and invite him first". 
same day, he was received by the Polish PM and told him that the HMG attached great importance to the Polish-Czech rapprochement (sic!) and believed that a good step in this direction would be to invite General Ingr to visit Polish military camps. Sikorski agreed without hesitation and promised that at the next scheduled meeting with Beneš, he would invite both the president of the CzPG and General Ingr to visit the Polish Military. He also noted with satisfaction that in the past, Beneš had not always been friendly to Poles, and he greatly modified his position, now showing a "more friendly spirit". He also informed the British ambassador about the meetings of presidents Raczkiewicz and Beneš ${ }^{45}$ and the refusal of the ministers of the Polish government to participate in the meeting of the Polish-Czech Society established by Filipowicz, the Czechoslovak part of which consisted of Hodža supporters ${ }^{46}$. In the FO, the result of the intervention was considered fully satisfactory. However, the political activity of Hodža and his supporters, described as "subversive", was still monitored and he was accused of intriguing against the CzPG together with "certain Poles". In a report on the topic prepared by Bruce-Lockhart, the creation of the "Polish-Czecho-Slovak Circle of Cultural Collaboration" was indicated as the most recent manifestation of these activities, where Filipowicz represented the Polish side. However, an attempt to call these meetings on 29 August failed completely as the invited individuals refused to participate. For the British, it was more important that, on 27 August, President Beneš was received by President Raczkiewicz, who paid back the visit the day after. Beyond the courtesy-propaganda dimension, it was of no significance but the gestures were positively received in the FO. There was also a meeting between ministers Stroński and Ripka, responsible for propaganda in their respective governments. To the satisfaction of the British, they agreed on a plan to revive Polish-Czech-Slovak cultural societies and coordinate their own propaganda activities ${ }^{47}$.

On 5 September, General Sikorski received Beneš during a private formal lunch. On 10 September, both gentlemen met again but more officially and in a larger group (with the participation of Ministers Zaleski, Kot, Stroński, General Sosnkowski and Ambassador Raczyński). A report from both meetings - in a version drafted by Beneš

45 TNA FO 371/24292 C 9401/8531/12, heading - p. 128.

46 TNA FO 371/24292 C 9361/8531/12, minutes by H.W. Kennard of 28 VIII 1940, pp. 126-127. FO also informed Bruce-Lockhart and Bridge about the effect of this intervention: TNA FO 688/29/2 w.p., letters of 29 VIII 1940 to R.H. Bruce-Lockhart and to Ch. Bridge.

47 TNA FO 371/24292 C 9401/8531/12, R.H. Bruce-Lockhart report for E. Halifax of 30 VIII 1940, p. 129; TNA FO 371/24292 C 9401/8531/12, A. Slaight letter to R.F. Cowell of 21 IX 1940, pp. 130-131. 
- was provided to Bruce-Lockhart, and represented the basis of a report he prepared for Lord Halifax. Thus, British diplomacy saw the course of the Polish-Czechoslovak talks primarily (but not exclusively) through Benešs eyes. He claimed that both politicians had come to a conclusion that in past, in Polish-Czechoslovak relations mistakes had been made which could not be repeated. He pointed to the strong Russophilia in Czechoslovakia, "mainly mystical in character", treated by him as an objective fact. He argued that friendship with Poland was a practical requirement, and as such it would be accepted by Czechoslovaks. He talked a lot about his own attempts to get closer to Warsaw before the war, blaming Minister Beck for their failure. Sikorski interrupted him by asking: "Do you still accept an arrangement with Poland as a preliminary condition to any Russo-Czecho-Slovak understanding", and having obtained confirmation from Beneš, he stated that "on that basis we can settle everything". Sikorski raised the need to harmonize Polish and Czechoslovak policies towards Moscow, suggesting Poland's need to abandon Piłsudski and Beck's “juggler's” policy - attempts to win Germany against Russia and vice versa in the face of a fundamental threat from Germany - for establishing good relations with the USSR, exactly what the Czechoslovak side was expected to help with. At the request of Beneš, it was established that the Polish side would not continue to "flirt" with Hodža, and it was considered that the border dispute in these circumstances was of lesser importance. To Beneš, the differences in the social structure of both countries (the Polish gentry mentality and Czech bourgeois mentality) were the main problem that could hold back mutual closeness but Sikorski pointed out that the war would change much in this respect. Another meeting in October was agreed, to discuss the opportunities of strengthening common interests, to develop issues common to both parties and eliminate contradictions. Bruce-Lockhart suspected that the common aversion to Minister Beck brought the leaders closer. He was also hopeful that this promising start of talks would bring fruitful results in the future. However, he expected opposition from some Polish and Czechoslovak politicians, and pointed to the need of being tactful and patient in eliminating a conviction that a majority of Poles believed that the Czechs and Slovaks were, in a social and cultural sense, inferior to them. In this, he also saw the main obstacle on the way to bringing both sides together. He also encouraged the British government to exert pressure on both governments to cooperate closely, which he considered beneficial to the $\mathrm{UK}^{48}$.

48 Quotations in this paragraph: TNA FO 417/42, C 9969/8531/12, R.H. Bruce-Lockhart's report to Halifax of 12 IX 1940, pp. 12-14 (print). 
Ten days after the second Sikorski-Beneš meeting, Kennard asked the Polish PM about his impressions as regards the talks he had held. The general was very satisfied with their course, emphasizing the polonophilism of the Czechoslovak president. He also assured him that Beneš had agreed to recognize that "the future relations of Czechoslovakia with the Soviets must be subordinated to those with Poland", and that the Czechoslovak government intended to consult with the Poles all the decisions that could affect mutual relations. At the same time, he proposed that the visit of General Ingr should be scheduled for the second half of October, as soon as the Polish units had moved to their designated camps in Scotland ${ }^{49}$. Roberts acknowledged the news coming to the FO on the development of Polish-Czechoslovak relations as a promising start but he expected that the talks scheduled for October would bring more concrete solutions. However, he thought that the real test of the permanence of the mutual sentiments would be the return of both governments to their countries. Nevertheless, he agreed that the British should continue to encourage them to cooperate ${ }^{50}$. During conversations with counsellors from the Polish embassy during lunch on 20 September, Makins heard from them that all Poles on the British Isles agreed on the need to prepare a working arrangement with the Czechs, recognizing that the stabilization of Eastern Europe after the war would depend on Polish-Czechoslovak cooperation. It was also envisaged that Hungary would be involved in the close cooperation. The Poles assumed that, due to the special relations between Poland and Hungary, they would be able to influence the end of the Czech-Hungarian rivalry. One way or another, it was considered that the Small Entente was dead and would be replaced by a policy of negotiation between the government of the RP and the Beneš group. Władysław Kulski, counsellor of the Polish Embassy in London, admitted to Makins that the Poles were not sure if "the Czechs were as keen on the new policy as the Poles" ${ }^{\text {. }}$.

The Czechoslovak message regarding the development of Polish-Czechoslovak relations and the future of Central Europe reached the FO with more details. This was owing to the reports by Bruce-Lockhart, who had had many opportunities to talk with Beneš, on the basis of which he shaped his views on the issues. At the same time, he was aware that at that stage of the war, with the outcome unknown, most

49 TNA FO 371/24292, C 9969/8531/12, H. Kennard's letter to Halifax of 20 IX 1940, p. 138.

50 TNA FO 371/24292, C 9969/8531/12, minutes by Roberts of 20 IX 1940, p. 132.

51 TNA FO 688/29/2, letter by R.M. Makins of 20 IX 1940; another copy - TNA FO 371/24292, C 9969/8531/12 or R.M. Makins minutes of 20 IX 1940, pp. 132-133. 
of the concepts he described had a mainly academic value. Yet the topic of PolishCzechoslovak relations was distinguished from the others, as being of practical significance as well ${ }^{52}$. He believed that war experiences had prompted Beneš to accept the idea of a federation of Central Europe and made him believe that the first step towards it should be establishing close cooperation between the RP and the ČSR. Both countries should be as homogeneous as possible by nationality. This would create a block of countries with approx. 30 million inhabitants: "Czechoslovaks" (this term was used) and Poles, required of Western Slavs to defend themselves against German pressure. At the same time, this federation would prevent Russia from dominating Germany and transferring the Bolshevik revolution to the shores of the English Channel. The given population indicated that Beneš thought about a connection with a smaller Poland, deprived of part of its eastern territories with an ethnically mixed population, as the pre-war Poland without ČSR itself exceeded the indicated limit of 30 million people. On the way to this federation, Beneš was ready to accept more than Bruce-Lockhart originally thought: a customs union, a common currency and a general staff with Poland. Each country would maintain a separate legal system regarding its internal affairs. A permanent Commission or Supreme Council would be established, consisting of Poles and "Czechoslovaks", which would deal with tariffs, transport and military matters. Beneš advocated for the longest possible border with Poland and the shortest possible with Germany. He stipulated that the suggested federation would not be a tool for conducting anti-German policy. He also expected that the USSR - as soon as it became aware of the strength of this federation - would strive to establish friendly relations with it. "He still cherishes the hope that Czechoslovaks might be able to build a bridge between Poland and Russia”. He saw the difficulties associated with Polish-Czechoslovak disputes, but he was optimistic about the chances of their resolution. He predicted that, at the end of the war, the Hungarians might want to join the planned federation, in which case he hoped that the Poles could play a role in Czechoslovak-Hungarian relations similar to that played by the Czechs in Polish-Russian relations: facilitating understanding between the nations. Beneš informed Bruce-Lockhart that he had discussed these assumptions with several members of the Polish government, and they all agreed that the action plan in this regard had to be prepared as soon as possible, and postponing it would be a mistake. Although some of the ideas voiced by

52 TNA FO 371/24289 C 10776/2/12, R.H. Bruce-Lockhart letter to Halifax of 7 X 1940, p. 231 (typescript - further on typewritten). 
Beneš were too ambitious, Bruce-Lockhart believed that the Polish-Czechoslovak federation was a desirable goal and "the only practical means at present available to us of filling the dangerous vacuum created by the collapse of the small states of Central Europe. If it can be achieved, it will set an admirable example to the Balkan States", he concluded ${ }^{53}$. The importance of Polish-Czechoslovak relations was also stressed to Bruce-Lockhart by Jan Masaryk, the Czechoslovak Foreign Minister, who set one of his priority tasks as "to complete some clear-out arrangement for Polish-Czechoslovak co-operation" 54 .

Beneš's ideas about the future of the ČSR and the political order in Central Europe, summarized in Bruce-Lockhart's reports, became the subject of the FO analyses. It was admitted there that only the concept of close Polish-Czechoslovak cooperation could be realized, recognizing the rest of the proposal as a matter of a distant and uncertain future. Roberts expressed an opinion that this cooperation was developing in a more satisfying way than originally supposed "even if the progress is up to the present all on paper". It was also recognized that the Poles in particular were satisfied with the developments. This assessment resulted from the analysis of Kennard's reports, who, on 9 October, had an opportunity to talk with Sikorski about the negotiations with the Czechoslovak side. The Polish PM believed that they were on a good track and had reached a point where they agreed that in the case of any projects for a federation of Central and Eastern Europe; the RP and the ČSR would take the lead in any such initiative. Kennard suggested that the Polish government made some statements on this topic on the BBC airwaves, which Sikorski promised to do during the next scheduled Sunday broadcast. He also informed the British ambassador of the final scheduling of the visit of General Ingr to the Polish military units in Scotland for the second half of October. He pointed to the progress in contacts between the general staffs of both armies, but admitted that the leadership of the Polish $2^{\text {nd }}$ Bureau - intelligence and counterintelligence - were hesitant about a closer relationship with the Head of the Czech $2^{\text {nd }}$ Bureau "as in the past he had been very much identified with the Bolsheviks and had even worked at Moscow for some time" ${ }^{\prime 5}$.

53 TNA FO 371/24289 C 10776/2/12, R.H. Bruce-Lockhart Memorandum for Halifax of 7 X 1940: Report of President Beneš's scheme for the restoration of Czechoslovakia and for the Reconstruction of Central Europe after the war, pp. 232-234 (typewritten).

54 TNA FO 688/29/2, R.H. Bruce-Lockhart report for Halifax of 8 X 1940 w.p.

55 TNA FO 371/24292 C 9969/8531/12, W.H. Kennard report to Halifax of 10 X 1940, p. 139. 
After the next meeting between Beneš and Sikorski (16 October), the Czechoslovak president summed it up to Bruce-Lockhard, informing him that he had submitted a proposal to the Polish PM to create a permanent Polish-Czechoslovak Committee of Co-operation. It would consist of an Executive Committee and four sub-committees. The Executive Committee would be responsible for developing general principles of cooperation defined by both governments. Four sub-committees would be appointed: for cultural, economic and financial, and propaganda cooperation, and for study of peace aims and post-war issues. Sikorski took these ideas favourably and asked Beneš to prepare a detailed memorandum in this regard. They also talked about the appropriate name for the planned union of states, agreeing that it could be a "Polish-Czechoslovak Commonwealth". Beneš was very pleased with the talks and expressed his sympathy for Sikorski and optimism about the further development of Polish-Czechoslovak relations ${ }^{56}$.

In the FO, Benešs ideas on the future organization of Central Europe were assessed as interesting and significantly "more supple" than could be expected. On the other hand, it was predicted that if the Germans were completely defeated in the war, the Russians could look at the Polish-Czechoslovak federation as a new "cordon sanitaire", depriving them of influence on the communists in Germany. In an event, however, in which the Germans were defeated, but not completely crushed, it was assumed that Moscow could look favourably at the Slavic block separating it from them. At this stage of the war, it was assessed that similar speculations were purely hypothetical, and what should and could be done was to encourage the Poles and Czechs (sic!) to cooperate ${ }^{57}$. Despite the apparent satisfaction with the progress of the Polish-Czechoslovak rapprochement, Roberts concluded that "in talking of a 'Polish-Czechoslovak Commonwealth' Dr. Beneš and General Sikorski are moving quite a long way" ${ }^{58}$. British diplomats did not realize, however, that just a few days earlier, in an interview with Maisky, Fierlinger argued that it was "the British who insist on Dr. Beneš communicating with the Poles. There is even talk of federalization. Dr. Beneš, however, rejects everything that would be directed against the [Soviet] Union (...) and what concerns the Soviet Union. Dr. Beneš tries to remain

56 TNA FO $371 / 24292$ C 11203/8531/12, R.H. Bruce-Lockhart report to Halifax of 16 X 1940, p. 146.

57 TNA FO 371/24289 C 10776/2/12, minutes by G.M. Warr of 13 X and F.K. Roberts and R.M. Makins of 14 X 1940, pp. 229-230.

58 TNA FO 371/24292 C 11203/8531/12, minutes by F.K. Roberts of 24 X 1940, p. 145. 
loyal as always" ${ }^{2}$. These statements shed a much less optimistic light on PolishCzechoslovak negotiations.

Meanwhile, in the eyes of the FO, the Polish-Czechoslovak communication had developed in the desired direction. In the Polish Hearth Club in London, on 9 October a meeting of ministers of both governments was held, with the participation of Presidents Raczkiewicz and Beneš, a ceremonial inauguration of work on the rapprochement between the two countries. The meeting was also attended by prominent British politicians: Minister of Economic Warfare, Hugh Dalton; Member of the House of Commons, Harold Nicolson; the parliamentary secretary of the Information Minister; and Bruce-Lockhart. The special attention of the British was drawn to a speech by Minister Stroński who emphasized the exiled community of fates of both nations and the necessity of their cooperation to enjoy victory ${ }^{60}$. The Polish government delegation also appeared on 28 October at the celebration of Czechoslovakia's Independence Day. The representative of the RP government at the CzPG had still not been appointed, as the considered candidates were abroad. Nevertheless, owing to Savery's skilful intervention, four Polish ministers participated in a solemn mass at St. James's, Spanish Place, and, in the afternoon, Minister Zaleski paid a courtesy visit to Beneš, President Raczkiewicz sent the head of his cabinet, and Sikorski was represented by General Izydor Modelski. All this was noted with great satisfaction by Bruce-Lockhart and brought to the attention of Lord Halifax and the $\mathrm{FO}^{61}$.

At the end of the month, Sikorski informed Kenneard that, on 31 October, the Polish Council of Ministers had adopted a draft of a joint Polish-Czechoslovak resolution, which was to be submitted to the CzPG for approval and, after its publication, published in both the UK and the US. The project declared solidarity and unity of views of both governments regarding the future reconstruction of Central and Eastern Europe $^{62}$. The prepared document was immediately presented to the CzPG. On 1 No-

59 Ref. 60, of 2 X 1940, [in:] ČSVDJ, p. 152. Also. in another interview with Maisky on 17 X 1940, Fierlinger explained the negotiations with the Poles with English pressure on Beneš - doc. No. 62, ibidem, p. 157.

60 TNA FO 371/24292, C 9969/8531/12, Polish-Czechoslovak Meeting, p. 140; M.K. Kamiński, Edvard Beneš kontra, p. 66.

61 TNA FO 371/24290 C 11819/2/12, R.H. Bruce-Lockhart's report to Halifax of 31 X 1940, p. 2 (typewritten).

62 TNA FO 371/24292, C 11782/8531/12, W.H. Kennard's report for Halifax of 31 X 1940, p. 150. On the circumstances of the Polish government's decision in this matter - see: M.K. Kamiński, Edvard Beneš kontra, pp. 68-70. 
vember, Beneš informed Bruce-Lockhart about this fact, declaring that he accepted the Polish proposal. It was supposed to announce the will of both parties to abandon their former antagonisms and create a "new unity of independent states" based on close political and economic cooperation, expressing the hope that other Central European countries would join this structure as well as broadly presenting the policy of terror and extermination of both nations led by Germany. Beneš stated that both he and Sikorski attached great importance to the publication of the text of the declaration before the elections in the USA, and he thought that it would be possible on 4 November. He also showed Bruce-Lockhart a memorandum he was going to hand over to Sikorski on $3 \mathrm{November}^{63}$, promising to deliver its copies to the FO. He also insisted on keeping it secret, justifying it with the concern that the Poles might reject or seriously alter the proposals therein, and, in that case, he would not want them to know that the original text was known to the British. Nevertheless, he stated that Polish-Czechoslovak unity was a political necessity for him, because there could not be a free Poland without a free ČSR and vice versa. Bruce-Lockhart had no doubt that Beneš valued highly General Sikorski, because at every conversation he did not fail to emphasize "the sincerity and common sense of the Polish Prime Minister". While appreciating the progress made towards Polish-Czechoslovak rapprochement, the British diplomat also saw the accompanying difficulties which had to be overcome. "In the background lurks the grim spectre of Teschen", he warned ${ }^{64}$. However, he looked at the issue from the Czechoslovak perspective, remembering only the responsibility of Minister Beck for the occupation of this territory by Poland in 1938, without mentioning the Czechoslovak military invasion of Cieszyn Silesia in 1919. The Czechs remembered it. During the discussion on the planned Polish-Czechoslovak declaration with H. Ripka (5 November), he claimed that when agreement was reached on more important issues, the issue of Cieszyn Silesia would no longer be so important. However, this provoked Dr Jan Karel Frágner - the head of the Czechoslovak Foreign Minister's office - to insist that this issue should not be omitted in talks with the Poles. He was of an opinion that Poles understood that the Czechs would not conduct an anti-Soviet policy, but they would not prevent Poles from arranging their affairs with

63 Probably, however, the memorandum was passed on to Sikorski on the same day - i.e. 1 XI 1940 - see ref. 28, [in:] CzPNECA, pp. 59-63; or TNA FO 371/24292, C 11983/8531/12, Echange des vues sur la collaboration polono-tchécoslovaque après la présente guerre, pp. 174-176. Extensive discussion in M.K. Kamiński, Edvard Beneš kontra, pp. 71-78.

64 TNA FO 417/42, C 11838/8531/12, R.H. Bruce-Lockhart report to Halifax of 1 XI 1940, pp. 33-34. 
the USSR. When he considered the problem of Cieszyn Silesia, he stated: "It will be like in 1920, we will use it when [the Poles] will be in trouble with Russia" ${ }^{65}$. Ripka warned that the lack of agreement with the Poles on this issue would put "Czechoslovaks" in a difficult situation at a peace conference, and ultimately the matter would be resolved by the British.

The Beneš memorandum for Sikorski provoked a discussion in the FO between Warr, Roberts, Makins and Strang. It was considered to be interesting, but with too few precise indications of what the planned Polish-Czechoslovak cooperation should consist of. Warr judged that the Czechs were indeed prepared to surrender very little of their sovereignty. He claimed that the memorandum was primarily aimed at creating a good atmosphere in the relations between the two governments. The Russian problem was deemed the most difficult for mutual relations, and he expected a firm Polish counter-proposition. To Roberts, the whole thing resembled the ideas discussed "in the ill-fated Committee on the Anglo-French Union", but he hoped that this time the efforts would be more fruitful. On the other hand, he agreed with Beneš, regarding the importance of the Russian factor and finding a power-factor in post-war Europe that could replace France in the role it played in 1918-1940. At the same time, he thought that Beneš had exaggerated the difficulties that prevented him from reaching an agreement in the Danube basin. He considered it appropriate to exclude the Cieszyn issue from current political discussions. Makins, however, referred to Marian Seyda the Polish Minister of Justice, who told him that the problem that could disrupt Polish-Czechoslovak cooperation was not just the issue of Cieszyn, but the issue of relations with Russia and Hungary. Seyda also pointed to the lack of a factor promoting the Polish-Czech agreement, which he considered crucial in a situation when the German threat in Eastern Europe would disappear as a result of the defeat of the Third Reich. The most optimistic commentary to the reviewed memorandum was formulated by Strang, for whom it was a signal confirming the will of both nations to create "a close Polono-Czech association after the war", which other countries "in the region could join". He saw in it the tendency to oppose the Nazi idea of the so-called "Neuordnung" (New Order) in Europe, linking Polish-Czechoslovak efforts with the Belgian proposal of merging the British and Belgian colonial empires ${ }^{66}$.

65 Národní Archiv, fond č. 1. H. Ripka 1-5-19-1, Záznam o informativní schúzce u státního tajemníka Dra Ripky dne 5. listopadu 1940. "Bude to jako r. 1920, využijeme toho, až budou v úzkých s Ruskem".

66 TNA FO 371/24292, C 11983/8531/12, minutes by G.M. Warr of 11 November, F.K. Rob- 
Meanwhile, on 2 November, Bruce-Lockhart sent Lord Halifax a text (still not final) of the Polish-Czechoslovak declaration, with the information that both governments had abandoned the idea of publishing it before the US elections, but planned to do it in a week or so ${ }^{67}$. Savery sent another copy - one received via Ciechanowski - to the $\mathrm{FO}^{68}$. The ministry's analysts were satisfied with the received text, although they decided to wait for its declaration with the official reaction and printing. Its date was still uncertain. The Czechoslovak side informed that it would take place on 9 November; the Poles, that it would be two days later. Even so, the FO decided that the text of the draft declaration was very good "and as far as both sides can go for the moment" and that it was necessary to give it the maximum publicity. At the same time, however, it was the British side which made a suggestion that the word "Provisional" should be added before "Czechoslovak Government" ${ }^{69}$. Baliński delivered the final text of the declaration to Makins to the FO on 9 November, announcing at the same time that it was to be announced by radio on 11 November - the Polish Independence Day - and published in the morning of 12 November with an earlier date. Receiving the document, Makins expressed his conviction that the declaration would get a great press in the UK. Baliński, however, stated that "it was of the greatest importance for the future"70. He admitted that originally it was intended to be announce at the Allied meeting, and that some references to it would probably be in the speech of General Sikorski. Charles Peake, head of the FO News Department, convened the Diplomatic Correspondents conference at 3:30 PM on 11 November,

erts of 12 November, R.M. Makins of 14 November and W. Strang of 14 XI 1940, pp. 170-171 and the letter of R.H. Bruce-Lockhart to Halifax of 5 XI 1940 with the attached text of the Benes memorandum, pp. 173-176.

67 TNA FO 417/42, C 11838/8531/12, letter from R.H. Bruce-Lockhart to Halifax of 2 November 1940, p. 34 and attachment: Final Amended Tet of Polish-Czechoslovak Declaration issued on November 11, 1940, pp. 34-35. Other copies with handwritten corrections: TNA FO $371 / 24292$, pp. 160-161. This text is almost no different from the final version. However, in a document published on 11 November, the phrase "the two Governments" had been consistently changed into the form: "The Polish Government and the Interim Czechoslovak Government" - cf. 29, [in:] CzPNECA, pp. 64-65.

68 TNA FO 371/24292, C 11782/8531/12, F. Savery's letter to F.K. Roberts of 1 XI 1940, together with the Draft of proposed Polish-Czechoslovak Declaration, pp. 151-153; TNA FO $688 / 29 / 2$, a letter from J. Ciechanowski to A. Howard of 1 XI 1940, together with the text of the declaration w.p.

69 TNA FO 371/24292, C 11838/8531/12, minutes by G.M. Warr and F.K. Roberts of 6 XI 1940 , note by W. Strang of 2 XI 1940, pp. 155-156.

70 TNA FO 371/24292, C 11838/8531/12, R.M. Makins minute of 9 XI 1940, p. 162 or p. 163. 
for which he invited Ministers Stroński and Ripka. "I shall preside and when they finished [reading the text of the declaration] I shall myself deliver an impassioned speech. Copies of the agreement will then be handed over in every known language to every correspondent who can be induced to take one. The leader writers of the principal morning papers will be bullied, bribed or cajoled into taking some notice of it"71 - as Peake wrote with some humour to Makins \& Strange, inviting both of the high-ranking FO officials to join the planned action. Strang decided, however, that the FO should not be too visible in this Polish-Czechoslovak enterprise. "We approve it wholeheartedly and desire the maximum publicity, but it should not appear that we sponsored the declaration", he stated ${ }^{72}$.

The Polish-Czechoslovak declaration of cooperation was announced on the set date - 11 XI 1940 - in the building of the British Ministry of Information, in the presence of Minister Stroński and Secretary of State Ripka. It was favourably received both by the British authorities and the public, who wanted to see in it a promising start of the desired post-war order in Central and Eastern Europe, where a mosaic of small countries formed after WWI would be replaced by larger federations, creating a better chance for the region's stability. This initiative, for reasons listed above, was supported from the beginning by the FO. Although it was aware of the difficulties that this ambitious project might encounter, and could even accurately indicate the main threats of it, the FO underestimated their scale and remained cautiously optimistic about the further developments. For the British side, this declaration was also of significance in its contemporary propaganda dimension. A lone fighter in the war, waging a deadly struggle with the Germans triumphing on the continent, the UK needed optimism, a signal of the strengthening of the Allied camp, which could be presented to the public as a success and a symbol of consolidation. The Polish-Czechoslovak Declaration of 11 XI 1940 met these expectations.

Nadesłany: 24 VI 2019

Nadesłany po poprawkach recenzyjnych: 13 VIII 2020

Zaakceptowany: 2 IX 2020

71 TNA FO 371/24292, C 11838/8531/12, minute by Ch. Peake of 9 XI 1940, p. 162.

72 TNA FO 371/24292, C 11838/8531/12, F.K. Roberts minute of 11 XI 1940, p. 162. 
prof. dr hab. Radosław Żurawski vel Grajewski

Uniwersytet Łódzki

Instytut Historii

ul. A. Kamińskiego 27a

90-219 Łódź

e-mail: rpzg@poczta.onet.pl

\section{Summary}

The idea of the Polish-Czechoslovak confederation was strongly supported by the British diplomacy during the first period of World War II. Foreign Office hoped that the creation of some federative union in Central and Eastern Europe was the best answer to the political fragmentation of the region and the only hope to supply the local nations with the fundamental conditions to maintain their independence in the light of both German and Soviet threats. The Polish government shared that conviction while Czechoslovak political emigration headed by Beneš was on the lookout for a political tool that would help their exiled authorities to achieve a status equal to the Polish government. The differences in the attitude towards the Soviet Union occurred the most important obstacle to close Polish-Czechoslovak collaboration in the future.

Translated by: Ewa Dratwa 